\title{
References
}

Alford, William (1995), To Steal a Book Is an Elegant Offense, Stanford, CA: Stanford University Press.

Allen Consulting Group (2001), 'The Economic Contribution of Australia's Copyright Industries', available at www.copyright.org.au/publications/ research/bcepv03.pdf (accessed 3 February 2010).

Arup, Christopher (2000), The New World Trade Organization Agreements:

Globalizing Law through Services and Intellectual Property, Cambridge:

Cambridge University Press.

$\mathrm{Au}$, Kin-fan (2009), 'The Maturing Apparel Industry in China', available at http://www.udel.edu/fiber/issue3/world/ApparelIndustry.html (accessed 3 February 2010).

Baranovitch, Nimrod (2003), China's New Voices: Popular Music, Ethnicity, Gender and Politics, Berkeley: University of California Press.

Barnett, Jonathan (2005), 'Shopping for Gucci on Canal Street: Reflections on Status Consumption, Intellectual Property and the Incentive Thesis', Virginia Law Review, 91 (6) [Online], available at http://www. virginialawreview.org/articles.php?article=76 (accessed 3 February 2010). Becker, Jasper (2000), The Chinese, London: John Murray Publishers. Beinhocker, Eric (2006), The Origin of Wealth, New York: Random House. Bettig, Ronald (1996), Copyrighting Culture: The Political Economy of Intellectual Property, Boulder, CO: Westview Press.

Boldrin, Michele and David K. Levine (2002), 'The Case against Intellectual Property', American Economic Review: Papers and Proceedings, 92 (2), 209-12.

Boldrin, Michele and David K. Levine (2005), 'The Economics of Ideas and Intellectual Property', Proceedings of the National Academy of Sciences, 102, 1252-6.

Boldrin, Michele and David K. Levine (2008), Against Intellectual Monopoly, Cambridge: Cambridge University Press.

BOP Consulting (2010), Literature Review: Changing Attitudes and

Behaviour in the 'Non-Internet' Digital World and Their Implications for Intellectual Property, London: Strategic Advisory Board on Intellectual Property.

Boyle, James (2004), 'A Manifesto on WIPO and the Future of Intellectual Property', Duke Law and Technology Review, 9, 1-12. 
Brace, Tim (1991), 'Popular Music in Contemporary Beijing: Modernism and Cultural Identity', Asian Music, 22 (2), 43-66.

Brady, Anne-Marie (2006), 'Guiding Hand: The Role of the CCP Central

Propaganda Department in the Current Era', Westminster Papers in

Communication and Culture, 3 (1), 57-76.

Breward, Christopher (2000), 'Cultures, Identities, Histories: Fashioning a Cultural Approach to Dress', in Nicola White and Ian Griffiths (eds), The Fashion Business: Theory, Practice, Image, Oxford and New York: Berg, pp. 23-36.

Breward, Christopher (2003), Fashion, Oxford: Oxford University Press.

Bruns, Axel (2008), Blogs, Wikipedia, Second Life, and Beyond: From Production to Produsage, New York: Peter Lang Publishing.

Burchell, Graham (1996), 'Liberal Government and Techniques of the Self', in Andrew Barry, Thomas Osborne and Nikolas Rose (eds), Foucault and Political Reason: Liberalism, Neo-liberalism and Rationalities of Government, London: University College London Press.

Burnett, Robert (1996), The Global Jukebox: The International Music Industry, London: Routledge.

Centre for Cultural Policy Research (2003), Baseline Study on Hong Kong's Creative Industries for the Central Policy Unit, Hong Kong Special Administrative Region Government, Hong Kong: University of Hong Kong.

Chang, Ha-Joon (2008), Bad Samaritans: The Myth of Free Trade and the Secret History of Capitalism, London: Random House Business Books.

Chang, Shaun (2009), 'Great Expectations: China's Cultural Industry and a Case Study of a Government-Sponsored Creative Cluster', Creative Industries Journal, 1 (3), 263-73.

Chen, Jianfu (1999), Chinese Law: Towards an Understanding of Chinese Law, Its Nature and Development, The Hague: Martinus Nijhoff Publishers. China Daily (2009), 'Copyright Centre Up and Running', available at http://www.chinaipr.gov.cn/news/enterprise/251165.shtml (accessed 10 February 2010).

China Economic Review (2004), 'Regulator Monster Biffs Spiderman', available at http://www.chinaeconomicreview.com/cer/2004_08/Regulator_ Monster_biffs_Spiderman.html (accessed 2 February 2010).

China Film Press (1995-2007), China Film Yearbook, Beijing: China Film Press.

China Mobile (2007), 'Interim Results', available at www.chinamobileltd. com/images/pdf/2007/ir_2007_e.pdf (accessed 3 February 2010).

China Mobile (2008), FAQ, available at http://www.chinamobileltd. com/ir.php?menu=5 (accessed 11 May 2008).

China Music Radar (2008), 'MIDI Festival Cancelled', China Music Radar 
[Online], 24 April, available at http://www.chinamusicradar.com/?p=15 (accessed 7 February 2010).

China Research Intelligence (2009), 'Report of Chinese Apparel Industry, 2009', available at http://www.thefreelibrary.com/Report+of+Chinese+ Apparel+Industry,+2009-a01073945145 (accessed 8 February 2010).

China Retail News (2008), 'Ministry of Commerce: China Will Become World's Biggest Luxury Market by 2014', China Retail News [Online], 18 April, available at http://www.chinaretailnews.com/2008/04/18/1134ministry-of-commerce-china-will-become-worlds-biggest-luxury-marketby-2014/ (accessed 4 February 2010).

China Tech News (2006), 'Hurray! Joins Hands with MTV', available at http://www.chinatechnews.com/2006/07/11/4260-hurray-joins-handswith-mtv/ (accessed 4 February 2010).

China Unicom (2008), Company Profile, http://www.chinaunicom.com.hk/en/ aboutus/profile.html (accessed 22 February 2008).

Chow, Daniel (2006), 'Counterfeiting and China's Economic Development', US-China Economic and Security Review Commission, 8 June, available at http://www.uscc.gov/hearings/2006hearings/written_testimonies/ 06_06_08wrts/06_06_7_8_chow_daniel.pdf (accessed 4 February 2010).

CMM Intelligence (2004), 'US Film Imports to Be Cut? SARFT: Yes . . . No . . . Maybe, I Don't Know . . . Can You Repeat the Question?', CMM Intelligence, 8 (4) [Online], available at http://www.cmmintelligence. $\mathrm{com} /$ ?q=node $/ 4510$.

CNNIC (2008), Statistical Survey Report on the Internet Development in China (January 2008), available at http://www.cnnic.cn/uploadfiles/pdf/ 2008/2/29/104126.pdf (accessed 25 July 2008).

CNNIC (2009), Statistical Survey Report on the Internet Development in China (July 2009), available at http://www.cnnic.net.cn/uploadfiles/pdf/ 2009/10/13/94556.pdf (accessed 4 February 2010).

Cohen, Wesley, Richard Nelson and John Walsh (2000), 'Protecting Their Intellectual Assets: Appropriability Conditions and Why U.S. Manufacturing Firms Patent (or Not)', National Bureau of Economic Research Working Paper no. W7552, available at http://papers.ssrn.com/ sol3/papers.cfm?abstract_id=214952 (accessed 4 February 2010).

Colvin, Mark (2006), 'China's Leaders "Riding the Tiger": Expert', $A B C$ Radio [Radio broadcast], 9 August, available at http://www.abc. net.au/pm/content/2006/s1711015.htm (accessed 8 February 2010).

Consumers International Asia Pacific Office (2006), Copyright and Access to Knowledge: Policy Recommendations on Flexibilities in Copyright Laws, Kuala Lumpur: Consumers International.

Coonan, Clifford (2008), 'China Tightens Rules on Foreign Performers', Variety [Online], $18 \mathrm{July,} \mathrm{available} \mathrm{at} \mathrm{http://www.variety.com/article/}$ VR1117989152.html?categoryid=16\&cs=1 (accessed 4 February 2010). 
Cox, Christine and Jennifer Jenkins (2005), 'Between the Seams, a Fertile Commons: An Overview of the Relationship between Fashion and Intellectual Property', available at http://learcenter.org/pdf/RTSJenkins Cox.pdf (accessed 3 February 2010).

Credit Suisse Equity Research (2005), China Internet Sector: Mobile Music Revolution in China, Sector Review, Zurich: Credit Suisse.

Crofton, I. (1988), A Dictionary of Art Quotations, London: Routledge.

Cunningham, Stuart (2006), What Price a Creative Economy?, Strawberry Hills, NSW: Currency House.

Cunningham, Stuart, John Hartley, Jason Potts, Arthur ter Hofstede, Julian Thomas, Denise Meredyth, Ellie Rennie and Brian Fitzgerald (2009), 'Submission to the Review of the National Innovation System', available at http://docs.google.com/viewer?a=v\&q=cache:pW1_CskPJ dEJ:www. innovation.gov.au/innovationreview/Documents/261-ARC-CCI.pdf+ Cunningham+Potts, + National+Innovation+Submission $\& \mathrm{hl}=$ en\&gl= uk\&sig=AHIEtbTn1uE0wITiIjsofQO7eMvGK0PkOQ (accessed 5 February 2010).

Daniel, Mathew (2007), 'So You Want to Sell Music in China?', available at http://outdustry.com/2008/01/17/so-you-want-to-sell-music-in-chinaguest-post/ (accessed 4 February 2010).

DCMS (1998), Creative Industries Mapping Document, London: HMSO.

DCMS (2010), 'Creative Industries', available at http://www.culture.gov.uk/ about_us/creative_industries/default.aspx (accessed 4 February 2010).

Deazley, Ronan (2006), Rethinking Copyright: History, Theory, Language, Cheltenham, UK and Northampton, MA, USA: Edward Elgar Publishing. de Beer, Jeremy (2009), 'Defining WIPO's Development Agenda', in Jeremy de Beer (ed.), Implementing the World Intellectual Property Organization's Development Agenda, Waterloo, ON: Wilfrid Laurier University Press.

de Kloet, Jeroen (2002), 'Rock in a Hard Place: Commercial Fantasies in China's Music Industry', in Stephanie Donald and Michael Keane (eds), Media in China: Consumption, Content and Crisis, London: RoutledgeCurzon, pp. 93-104.

Dixon, Padraig and Christine Greenhalgh (2002), 'The Economics of Intellectual Property: A Review to Identify Future Research Directions', Nuffield College Working Paper no. 0502 [Online], available at www.oiprc.ox.ac.uk/EJWP0502.pdf (accessed 4 February 2010).

Dopfer, Kurt and Jason Potts (2004), 'Evolutionary Foundations of Economics', in J. Stanley Metcalfe and John Foster (eds), Evolution and Economic Complexity, Cheltenham, UK and Northampton, MA, USA: Edward Elgar Publishing.

Dopfer, Kurt and Jason Potts (2008), The General Theory of Economic Evolution, London: Routledge. 
Drahos, Peter and John Braithwaite (2002), Information Feudalism: Who Owns the Knowledge Economy?, London: Earthscan Publications.

Economist (2006), 'No Direction: Everyone Is in Love with Chinese Cinema. Except the Chinese' [Print edition], 27 April.

Endeshaw, Assafa (1999), Intellectual Property in China: The Roots of the Problem of Enforcement, Singapore: Acumen Publishing.

European Audiovisual Observatory (2009), Marché du Film 2009: World Film Market Trends, available at http://www.international-television. org/tv_market_data/focus_world_film_market_trends_statistics.html (accessed 11 May 2010).

European Commission (2008), '2007 Customs Seizures of Counterfeit Goods - Frequently Asked Questions', Press Release [Online], 19 May, available at http://europa.eu/rapid/pressReleasesAction.do?reference=MEMO/ 08/310 (accessed 4 February 2010).

Ewan, Elizabeth (1990), Townlife in Fourteenth Century Scotland, Edinburgh: Edinburgh University Press.

Fine, Jon (2007), 'Opinion: Leaving Record Labels Behind', Business Week [Online], available at http://www.businessweek.com/magazine/content/ 07_44/b4056094.htm (accessed 7 February 2010).

Farrell, Diana, Ulrich Gersch and Elizabeth Stephenson (2006), 'The Value of China's Emerging Middle Class', McKinsey Quarterly, 2006 special edition: Serving the New Chinese Consumer, New York: McKinsey \& Company, pp. 60-69.

Finnane, Antonia (2007), Changing Clothes in China: Fashion, History, Nation, London: Hurst Publishers.

Fisher, Marshall, Janice Hammond, Walter Obermeyer and Annath Raman (1994), 'Making Supply Meet Demand in an Uncertain World', Harvard Business Review, May-June, 83-93.

Fitzgerald, Anne and Brian Fitzgerald (eds) (2004), Intellectual Property in Principle, Sydney: Lawbook Company.

Foucault, Michel ([1961] 1989), Madness and Civilization: A History of Insanity in the Age of Reason, translated from French by Richard Howard, London and New York: Routledge.

Foucault, Michel (1972), The Archaeology of Knowledge, translated from French by S. Smith, London: Routledge.

Foucault, Michel (1978), The History of Sexuality, Vol. 1: An Introduction, translated from French by R. Hurley, Harmondsworth: Penguin.

Foucault, M. (1984), 'What Is Enlightenment?', in The Foucault Reader, ed. P. Rabinow, New York: Pantheon.

Foucault, Michel (1985), The History of Sexuality, Vol. II: The Use of Pleasure, translated by R. Hurley, London: Penguin.

Foucault, Michel (1986), The History of Sexuality, Vol. III: The Care of the Self, translated by R. Hurley, London: Penguin. 
Foucault, Michel (1988), 'Technologies of the Self', in Patrick Hutton (ed.), Technologies of the Self: A Seminar with Michel Foucault, Amherst: University of Massachusetts Press.

Foucault, Michel (2002), Power: Essential Works of Foucault 1954-1984, translated from French by Robert Hurley, ed. James Faubion, London: Penguin Books.

Frith, Simon (2004), 'Copyright, Politics and the International Music Industry', in Simon Frith and Lee Marshall (eds), Music and Copyright, Edinburgh: Edinburgh University Press, pp. 70-88.

Gilbert, Richard and Carl Shapiro (1990), 'Optimal Patent Length and Breadth', RAND Journal of Economics, 21, 106-12.

Ginsburg, Jane (1992), 'Moral Rights in a Common Law System', in Peter Anderson and David Saunders (eds), Moral Rights Protection in a Copyright System, Brisbane: Griffith University Press.

Grinvald, Leah (2008), 'Making Much Ado about Theory: The Chinese Trademark Law', Michigan Telecommunications and Technology Law Review, 15 (53), 53-106.

Gronow, Pekka and Ilpo Saunio (1999), International History of the Recording Industry, translated from Finnish by Christopher Moseley, London: Continuum International.

Halbert, Debora (1999), Intellectual Property in the Information Age: The Politics of Expanding Ownership Rights, London: Quorum Books.

Hancock, Terry (2006), 'The Case for a Creative Commons "Sunset" NonCommercial Licence Module', Free Software Magazine [Online], 31 May, available at www.freesoftwaremagazine.com/node/1566 (accessed 2 February 2010).

Hartley, John (2005), 'Creative Industries', in John Hartley (ed.), Creative Industries, Oxford: Blackwell, pp. 1-40.

Hartley, John (2009), The Uses of Digital Literacy, Saint Lucia: University of Queensland Press.

Hartley, John and Lucy Montgomery (2009), 'Fashion as Consumer Entrepreneurship: Emergent Risk Culture, Social Network Markets, and the Launch of Vogue China', Chinese Journal of Communication, 2 (1), 61-76.

Hill, Daniel D. (2004), As Seen in Vogue: A Century of American Fashion in Advertising, Lubbock: Texas University Press.

Hindess, Barry (1996), Discourses of Power: From Hobbs to Foucault, Oxford: Blackwell.

Hirshleifer, Jack (1971), 'The Private and Social Value of Information and the Reward to Inventive Activity', American Economic Review, 61, 561-74.

HKTDC (2008), 'China's Luxury Consumption Market Heating Up', available at http://www.hktdc.com/info/vp/a/tjo/en/1/3/1/1X003GM2/China-S- 
Luxury-Consumption-Market-Heating-Up.htm (accessed 4 February 2010).

Hooper, Beverley (1994), 'From Mao to Madonna: Sources on Contemporary

Chinese Culture', Southeast Asian Journal of Social Science, 22, 161-9.

Hooper, Beverley (1998), 'Flower Vase and Housewife: Women and

Consumerism in Post-Mao China', in Krishna Sen and Maila Stivens (eds),

Gender and Power in Affluent Asia, Routledge: London, pp. 167-93.

Howkins, John (2001), The Creative Economy, London: Penguin.

Howkins, John (2005), 'Creativity, Innovation and Intellectual Property: A

New Approach for the 21st Century', Paper presented at the 2005 Shanghai International IPR Forum, Shanghai, 2 December.

Hua, Jin (2004), 'Strengthen the Capital Market and Increase the Drive of the

Cultural Industry', Paper presented to 2nd Annual Cultural Industries

Conference, Taiyuan, Shanxi Province, 12-15 September.

Hui, Desmond (ed.) (2006), Study on the Relationship between Hong Kong's

Cultural and Creative Industries and the Pearl River Delta, Hong Kong:

Centre for Cultural Policy Research, University of Hong Kong.

Hui, Sylvia (2005), 'Massive Support Vowed for Creative Industries', The Standard [Online], 13 January, available at http://www.thestandard. com.hk/stdn/std/Front_Page/GA13Aa08.html (accessed 3 February 2010).

Hunt, Ken (2007), 'Welcome to the Radiohead Economy', Globe and Mail

[Online], 29 November, available at http://www.theglobeandmail.com/ report-on-business/article799838.ece (accessed 3 February 2010).

Hurray (2008), 'Company Introduction', available at http://www.hurray.com. cn/english/about_intro.htm (accessed 4 February 2010).

Ikels, Charlotte (1996), The Return of the God of Wealth: The Transition to a Market Economy in Urban China, Stanford, CA: Stanford University Press. International Federation of Phonographic Industries (2008), 'Recording Industry Steps Up Its Campaign against Internet Piracy in China', available at http://www.ifpi.org/content/section_news/20080204.html (accessed 11 May 2010).

International Federation of the Periodical Press (2006), 'China', FIPP World Magazine Trends 2006/7 [Online], available at http://www.fipp.com/ News.aspx ?PageIndex=2002\&ItemId=13502 (accessed 3 February 2010). International Telecommunications Union (2008), The China and Hong Kong SAR ICT Markets, available at http://www.itu.int/world2006/forum/ china_hong_kong_sar.html (accessed 11 May 2010).

Jayasuriya, Kanishka (2001), 'The Rule of Law and Governance in East Asia', in Mark Beeson (ed.), Reconfiguring East Asia: Regional Institutions and Organisations after the Crisis, London: Curzon, pp. 99-116.

Jia, Wei (1998), 'China's Film Industry: Crisis or Transition', Ph.D. thesis, Australian National University, Canberra. 
Keane, Michael (2007), Created in China: The Great New Leap Forward, London: Routledge.

Keane, Michael (2009), 'Understanding the Creative Economy: A Tale of Two Cities' Clusters', Creative Industries Journal, 1 (3), 211-26.

Keane, Michael and Stephanie Hemelryk Donald (2002), 'Responses to Crisis: Convergence, Content Industries and Media Governance', in Stephanie Hemelryk Donald and Michael Keane (eds), Media in China: Consumption, Content and Crisis, London: RoutledgeCurzon, pp. 200-211.

Kennedy, John (2006), 'Unlocking the Music Market in China', Speech delivered at the China International Forum on the Audio Visual Industry, Shanghai, 25 May, available at http://www.ifpi.org/content/section_views/ view020.html (accessed 11 May 2010).

Kraus, Richard (2004), The Party and the Arty in China: The New Politics of Culture, Oxford: Rowman \& Littlefield.

Kwan, Chi Hung (2008), 'Accelerating Appreciation of the RMB - A Major Step toward a Free Floating Exchange Rate System', China in Transition [Online], 8 May, available at http://www.rieti.go.jp/en/china/ 08050801.html (accessed 3 February 2010).

Kynge, James (2007), China Shakes the World: The Rise of the Hungry Nation, London: Phoenix.

Laing, Dave (2002), 'Copyright as a Component of the Music Industry', in Michael Talbot (ed.), The Business of Music, Liverpool: Liverpool University Press, pp. 171-94.

Lancaster, A. (2001), 'Hollywood vs China', City Weekend, 20 December.

Lanham, Richard (2006), The Economics of Attention, Chicago: University of Chicago Press.

Law, Ryan (2004), 'Cross-Border Traffic Co-productions between Hong Kong and Mainland China', Far East Film [Online], available at http://194.21.179.166/cecudine/datahost/fef2004/english/hongkong2004_3 .html (accessed 22 October 2004).

Lemire, B. and G. Iello (2008), 'East and West: Textiles and Fashion in Early Modern Europe', Journal of Social History, 41 (4).

Lerner, Josh and Jean Tirole (2002), 'Some Simple Economics of Open Source', Journal of Industrial Economics, 50, 197-234.

Lessig, L. (2001), The Future of Ideas: The Fate of the Commons in a Connected World, New York: Random House.

Lessig, Lawrence (2004), Free Culture: How Big Media Uses Technology and the Law to Lock Down Culture and Control Creativity, New York: Penguin Press.

Liao, Han-Teng (2006), 'Towards Creative Da-Tong: An Alternative Notion of Creative Industries for China', International Journal of Cultural Studies, 9 (3), 395-406. 
Liebowitz, Stan (1985), 'Copying and Indirect Appropriability: Photocopying of Journals', Journal of Political Economy, 95 (5), 945-57.

Lipsitz, George (1994), 'Who'll Stop the Rain? Youth Culture, Rock 'n' Roll, and Social Crises', in David Farber (ed.), The 60's: From Memory to History, Chapel Hill: University of North Carolina Press, pp. 206-34.

Litman, Jessica (2001), Digital Copyright, Amherst, NY: Prometheus Books. Liu, Deming (2006), 'The Transplant Effect of Chinese Patent Law', Chinese Journal of International Law, 5 (3), 733-52.

Luppino, T. (2001), 'The True Art of a Copy Cat', Cloudband Magazine [Online], http://www.cloudband.com/magazine.articles2q01/exh_luppino _copying_050h.html (accessed 25 May 2005).

Marshall, Lee (2005), Bootlegging: Romanticism and Copyright in the Music Industry, London: Sage.

Maskus, Keith (2000), Intellectual Property Rights in the Global Economy, Washington, DC: Institute for International Economics.

McCormack, Richard (2006), 'China Replaces US as World's Largest Apparel Exporter: Trade Imbalances Could Cause Financial Upheaval; MAPI Analyst Implores U.S., IMF to Act Now on China's Yuan', Manufacturing and Technology News, 13 (16) [Online], available at http://www.manufacturingnews.com/news/06/0905/art1.html (accessed 3 February 2010).

McCullagh, Charles (2005), 'China: Clarification of Media Investment Regulations', Magazine Publishers of America [Online], available at http://www.magazine.org/international/13175.aspx (accessed 11 May 2010).

Mertha, Andrew (2005), The Politics of Piracy: Intellectual Property in Contemporary China, New York: Cornell University Press.

Miller, Toby, Nitin Govil, John McMurria, Richard Maxwell and Ting Wang (2005), Global Hollywood 2, London: British Film Institute.

Mills, Sara (2003), Michel Foucault, London: Routledge.

Ministry of Information and Industry (2008), March 2008 Telecommunications Industry Statistical Report, http://www.mii.gov.cn/art/ 2008/04/25/art_54_37170.html (accessed 8 March 2008).

Moller, Erik (2005), 'Are Creative Commons-NC Licenses Harmful?', Podcasting News, [Online], 4 October, available at http://www.podcastingnews.com/archives/2005/10/are_creative_co.html (accessed 3 February 2010).

Montgomery, Lucy and Brian Fitzgerald (2006), 'Copyright and the Creative Industries in China', International Journal of Cultural Studies, 9 (3), 407-18.

MPAA (2004), 'MPAA Calls on USTR to Use Special 301 to Leverage Pakistan, Russia, Taiwan, Malaysia and China to Reduce Piracy', available at www.ftac.net/6-MPAA_and_301.pdf (accessed 4 February 2010). 
Murphy, Kevin, Benjamin Klein and Andres Lerner (2002), 'Intellectual Property: Do We Need It? The Economics of Copyright Fair Use in a Networked World', American Economic Review: Papers and Proceedings, 92 (2), 205-8.

Music 2.0: Exploring Chaos in Digital Music (2008), 'iTuneless iPod Faces Music Piracy in China', available at http://www.music2doto.com/ archives/111 (accessed 15 December 2008).

National Animation Industry Base (n.d.), National Animation Industry Base, Wuxi: National Animation Industry Base.

National Bureau of Statistics of China (2005), China Statistical Yearbook, Beijing: National Bureau of Statistics of China.

O'Connor, Justin and Gu Xin (2006), 'A New Modernity? The Arrival of "Creative Industries" in China', International Journal of Cultural Studies, 9 (3), 271-83.

Office of the United States Trade Representative (2009), 2009 Special 301

Report [Online], 30 April, available at http://www.mcit.gov.eg/General/ IPR \% 20Report \% 202009\% 20by\%20the\%20Office\% 20 of $\% 20$ the $\%$ 20United\%20States\%20Trade\%20Representative2009517161614.pdf (accessed 4 February 2010).

Okonkwo, Uki (2007), Luxury Fashion Branding, Houndmills, Hampshire: Palgrave Macmillan.

Paloczi-Horvath, George (1963), Mao Tse Tung: Emperor of the Blue Ants, Garden City, NY: Doubleday.

Peerenboom, Randall (2002), China's Long March towards Rule of Law, Cambridge: Cambridge University Press.

Peto, Ed (2007), 'Enter the Dragon: Introduction to the Music Business in China', China.Music [Online], available at http://outdustry.com/ 2007/11/05/enter-the-dragon-introduction-to-the-music-business-in-china/ (accessed 3 February 2010).

Phillips, Jeremy and Alison Firth (2001), Introduction to Intellectual Property Law, London: Butterworths LexisNexis.

Potts, Jason (2003), 'Evolutionary Economics: An Introduction to the Foundation of Liberal Economic Philosophy', Discussion Papers Series no. 324, University of Queensland School of Economics, Brisbane.

Potts, Jason and Stuart Cunningham (2008), 'Four Models of Creative Industries', International Journal of Cultural Policy, 14 (3), 133-47.

Potts, Jason, Stuart Cunningham, John Hartley and Paul Ormerod (2008), 'Social Network Markets: A New Definition of the Creative Industries', Journal of Cultural Economics, 32 (3), 167-85.

Qu, Sanqiang (2002), Chinese Copyright Law, Beijing: Foreign Languages Press.

Romer, Paul (2002), 'When Should We Use Intellectual Property Rights?', American Economic Review: Papers and Proceedings, 92 (2), 213-16. 
Royal Society for the Arts (2005), Adelphi Charter on Creativity, Innovation and Intellectual Property, available http://www.adelphicharter.org/adelphicharter.asp (accessed 3 February 2010).

Ruggieri, Maria (2002), 'Market Forces: Chinese Cinema in 2002', Asian Film Connection [Online], available at http://www.asianfilms.org/ edres_links_detail.php?regionid $=1 \&$ countryid $=1 \&$ edlinkid $=31 \% 20 \&$ PHP SESSID=fd9d0 (accessed 3 February 2010).

Sauvé, Pierre, Olivier Barlet, Emmanuel Cocq, Madanmohan Rao, German Rey and Craig Van Grasstek (2006), 'Trends in Audiovisual Markets: China, Mongolia and South Korea', available at http://portal.unesco.org/ci/en/ev.php-URL_ID=22361\&URL_DO= DO_TOPIC\&URL_SECTION=201.html (accessed 15 May 2010).

Scott, Ajax (2005), 'UK Companies Aim to Crack Fast-Changing Chinese Market', Music Week [Online], 17 December, available at http://goliath.ecnext.com/coms2/gi_0199-5093751/UK-companies-aim-tocrack.html (accessed 3 February 2010).

Seidman, Anne and Robert Seidman (1994), State and Law in the Development Process: Problem-Solving and Institutional Change in the Third World, New York: St. Martin's Press.

Selden, Mark (1995), China in Revolution: The Yenan Way Revisited, New York and London: M.E. Sharpe.

Sheng, Lu (2009), 'The Outlook for U.S.-China Textile and Apparel Trade in 2009: From the Trade Policy Perspective', Fiber, 3, available at http://www.udel.edu/fiber/issue3/world/ApparelTradeOutlook.html (accessed 3 February 2010).

State Administration of Radio, Film and Television (2003), 'Interim Provisions on the Access of Operational Qualifications for Movie Production, Distribution and Projection', Laws of the People's Republic of China [Online], 29 October, available at http://www.asianlii.org/cn/legis/ cen/laws/ipotaooqfmpdap1103/ (accessed 7 February 2010).

Steele, Valerie (2000), 'Fashion: Yesterday, Today and Tomorrow', in Nicola White and Ian Griffiths (eds), The Fashion Business: Theory, Practice, Image, Oxford: Berg, pp. 7-20.

Sun, Liping (2006), "China Leapfrogs into a "Digital Music Age": International Recording Industry Giants Converge at Music Fair', Xinhua Net [Online], 16 May, available at http://news.xinhuanet.com/newmedia/2006-05/17/content_4555754.htm (accessed 4 February 2010) (in Chinese).

Sun, Shaoyi (2000), 'Under the Shadow of Commercialization: The Changing Landscape of Chinese Cinema', Celluloid, April, 1-6.

Tabarrok, Alexander (2002), 'Patent Theory versus Patent Law', B.E. Journal of Economic Analysis and Policy, 1 (10) [Online], available at 
http://www.bepress.com/bejeap/contributions/vol1/iss1/art9/ (accessed 2 February 2010).

Towse, Ruth (2001), Creativity, Incentive and Reward, Cheltenham, UK and Northampton, MA, USA: Edward Elgar Publishing.

Treverton, Gregory, Carl Matthies, Karla Cunningham, Jeremiah Goulka, Greg Ridgeway and Anny Wong (2009), Film Piracy, Organised Crime, and Terrorism, Santa Monica, CA: RAND Corporation.

UK Trade and Investment (2004), 'Changing China - The Creative Industry Perspective: A Market Analysis of China's Digital and Design Industries', available at http://www.eastmids-china.co.uk/uploads/creativeindustry.pdf (accessed 4 February 2010).

UNESCO (2005), 'International Flows of Selected Cultural Goods and Services 1994-2003', available at www.uis.unesco.org/template/ pdf/cscl/IntlFlows_EN.pdf (accessed 4 February 2010).

van Schijndel, Marieke and Joost Smiers (2005), 'Imagine a World without Copyright', International Herald Tribune [Online], 8 October, available at http://www.iht.com/articles/2005/10/07/opinion/edsmiers.php (accessed 3 February 2010).

Veblen, Thorstein (1899), The Theory of the Leisure Class: An Economic Study of Institutions, reprinted in Michael Lewis (ed.) (2007), The Real Price of Everything: Rediscovering the Six Classics of Economics, New York: Sterling Publishing.

Wan, Jihong and Richard Kraus (2002), 'Hollywood and China as Adversaries and Allies', Public Affairs, 75 (3), 419-34.

Wang, Jing (2004), 'The Global Reach of a New Discourse: How Far Can “Creative Industries” Travel?', International Journal of Cultural Studies, 7 (1), 9-19.

Wang, Shujen (2003), Framing Piracy, Lanham, MD: Rowman \& Littlefield. Wang, Yumei (2008), 'Sun Shoushan: Our Country Has Authorized 59

Chinese and Foreign Periodical Cooperative Projects', Xinhua Net [Online], 3 April, available at http://news.xinhuanet.com/newmedia/200804/03/content_7913167.htm (accessed 3 February 2010) (in Chinese).

Wood, Hannah (2009), 'Fake Brands Shopping Centre Set to Open in China Pictures', Mirror [Online], 5 January, available at http://www.mirror.co.uk/ news/top-stories/2009/01/05/fake-brands-shopping-centre-set-to-open-inchina-pictures-115875-21018152/ (accessed 7 February 2010).

World Economic Forum (2008), 'China Must Take Steps to Boost Domestic Consumption', Press Release [Online], 28 September, available at http://www.weforum.org/en/media/Latest\%20Press\%20Releases/PR_AM NC08_Cons (accessed 4 February 2010).

Wu, Juanjuan (2009), Chinese Fashion: From Mao to Now, Oxford and New

York: Berg. 
Xu, Gary (2007), Sinascape: Contemporary Chinese Cinema, Lanham, MD and Plymouth: Rowman \& Littlefield.

Xue, Hong and Zheng Chengshi (2002), Chinese Intellectual Property Law in the 21st Century, Hong Kong, Singapore and Petaling Jaya, Malaysia: Sweet \& Maxwell Asia.

Yan, Jiaqi and Gao Gao (1996), Turbulent Decade: A History of the Cultural Revolution, translated and edited by D.W.Y. Kwok, Honolulu: University of Hawai'i Press.

Yao, C. (2007), 'A Prosperous Market of Wireless Music', Communicate, 1 (28) [Online], available at http://www.huawei.com/publications/ view.do?id=1621\&cid=3162\&pid=61 (accessed 3 February 2010).

Yung, Danny (2003), 'Creative Industry, Creative Hong Kong Forum', available at http://www.cpu.gov.hk/english/documents/conference/20030924 Opening\%20Speech.pdf (accessed 4 February 2010).

Yurchak, Alexei (2002), 'Entrepreneurial Governmentality in Post-Socialist Russia: A Cultural Investigation of Business Practices', in Victoria Bonnell and Thomas Gold (eds), The New Entrepreneurs of Europe and Asia, New York: M.E. Sharpe, pp. 278-324.

Zhang, Yingjin (2004), Chinese National Cinema, New York: Routledge.

\section{LIST OF INTERVIEWS}

Chen, Daming (2004), director and producer, interview with the author, Beijing, 18 March.

Chen, Xiang (2009), Shanghai Shiyi Company Limited, director, interview with the author, Shanghai, 27 April.

$\mathrm{Hu}$, Bo (2004), Beijing Longevity Digital Entertainment Production Company, director, producer, interview with the author, Beijing, 15 July.

Huang, Beaker (2005), Warner Music China, marketing and business development director, interview with the author, Beijing, 10 August.

Huang, Qunfei (2009), New Film Association, general manager, interview with the author, Beijing, 1 April.

Hung, Huang (2005), China Interactive Media Group, chief executive officer, interview with the author, Beijing, 12 August.

Jia, Qi (2009), Academy of Fine Arts, Harbin Normal University, associate director, interview with the author, 13 April, Beijing.

Kuo, Kaiser (2007), Ogilvy, group director for digital media, interview with the author, Beijing, 31 October.

Lan, Simon (2005), Beijing Frontline Productions, producer, interview with the author, Beijing, 24 June. 
Li, Wei (2009), Tsinghua University School of Art and Design, associate professor, interview with the author, Beijing, 27 March.

Li, Yang (2004), Tang Splendour Film Company, director, producer, interview with the author, Beijing, 5 May.

Liu, Xinxin (2009), Tsinghua University School of Art and Design, lecturer and independent artist, interview with the author, Beijing, 20 March.

Tang, Terry (2007), Noank Media, director of China business development, interview with the author, Beijing, 2 November.

Wang, Jade (2005), deputy channel director, Easy FM, China Radio International, interview with the author, Beijing, 2 August.

Wang, Shi (2004), Chinese Culture Protection Society, interview with the author, Beijing, 1 August.

Wang, Zhebin and Wang, Xingdong (2004), Beijing Forbidden City Film Company: Grade A screenwriter, film producer; and Grade A screenwriter, president Script Writers Guild of China, delegate Chinese People's Consultative Conference, interview with the author, Beijing, 8 May.

Wulan, Tana (2004), Xian Film Studios, director, interview with the author, Beijing, 15 July.

Zhao, Daniel (2005), Huayi Music, vice general manager, interview with the author, Beijing, 9 August.

Zhu, Baixi (2009), Fougere 2, co-founder and designer, interview with the author, Shanghai, 18 April. 
Lucy Montgomery - 9781849804707

Downloaded from PubFactory at $04 / 26 / 2023$ 02:46:41PM

via free access 